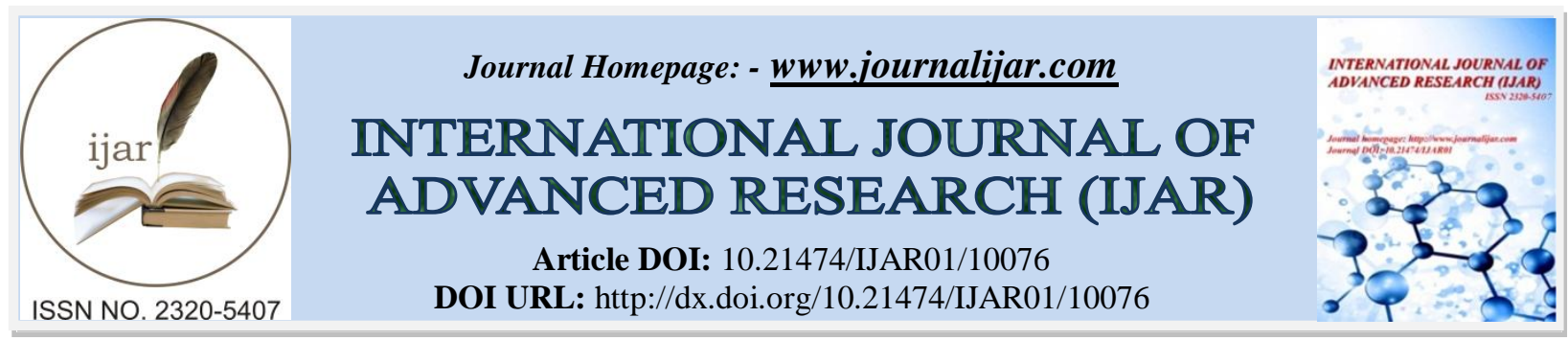

RESEARCH ARTICLE

\title{
A ONE YEAR RETROSPECTIVE STUDY OF HISTOPATHOLOGICAL LESIONS OF HEAD AND NECK.
}

Dr. Yogita Singh Tomar, Dr. Preeti Lahari, Dr.Priyanka Agrawal and Dr. U.R. Singh.

Department of Pathology, Shyam Shah Medical College Rewa, Madhya Pradesh, India.

\section{Manuscript Info}

\section{Manuscript History}

Received: 12 September 2019

Final Accepted: 14 October 2019

Published: November 2019

Keywords:

Head, neck lesion.

\begin{abstract}
Introduction:Head and neck lesions are commonly encountered in patients of all age group including skin, soft tissue, thyroid, lymph node, salivary gland, eye, nose, oral, otologic, etc, include a spectrum of lesions ranging from simple benign to highly malignant, contribute to significant morbidity and mortility.

Aims \& Objective: To determine histopathological subtypes, frequency of head \& neck lesion, age, gender distribution and site \& organ wise distribution

Methodology: A one year retrospective study was designed to study of various biopsies from head and neck region, sent for HPE at department of pathology, SSMC, Rewa, M.P. from $1^{\text {st }}$ Nov 2018 to $31^{\text {st }}$ Oct 2019

Result:Total 186 cases from the head and neck region were analyzed .Age range was 4 years to 89 years. With maximum cases were in the age group of 11-30 years (60.2\%).M:F ratio was 1.16:1. In our study, $55.9 \%$ benign, $33.3 \%$ inflammatory, $6.5 \%$ malignant lesion. Squamous cell carcinoma was the most common malignant lesion

Conclusion:We conclude that site specific data like this is helpful in evaluating patterns of head and neck lesions and augment the baseline data of institute and region.
\end{abstract}

Copy Right, IJAR, 2019,. All rights reserved.

\section{Introduction:-}

Head and Neck lesion are very common in day to day practice. These lesions can be seen in all the age groups.(1)This region encompass a multitude of inflammatory or neoplastic lesions. Various anatomic sites include oral, upper aero-digestive tract, otologic, thyroid, salivary glands, lymph node, skin \& soft tissues. $(2,3)$ Head \& neck neoplasia are the $7^{\text {th }}$ most common malignancy worldwide, accounting for $23 \%$ of all cancer in males and $6 \%$ in females. $(4,5)$ The present study is aimed to review the histological patterns of biopsied head \& neck lesions as information regarding the types \& frequencies of lesion, age, sex, site wise \& involved organ wise distribution of lesions.

\section{Material And Method:-}

The study was conducted in the dept. of pathology, SSMC, SGMH,Rewa. This retrospective study was done in the duration of one year from $1^{\text {st }}$ Nov. 2018 to $31^{\text {st }}$ Oct 2019. All histopathological data of head and neck lesions, maintained in the histopathology section were retrieved and reviewed. All the formalin fixed specimen were 
receieved, after grossing, processing wass done, prepared slides were stained with H\& E stain and after slide analysis by microscopy histolopathological diagnosis were established.

\section{Results:-}

A total of 186 cases from the head \& neck region were analyzed The patients ages ranged from 4 year to 89 years. More than half of the lesions $(60.2 \%)$ were noted in the age group of 11 to 40 years. There were 100 male \& 86 female, ratio was 1.16:1.

Table 1:-Age Wise Distribution of lesion:-

\begin{tabular}{|l|l|l|}
\hline Age group ( In years) & No. of Cases & \% Of Cases \\
\hline $0-10$ & 6 & $3.2 \%$ \\
\hline $11-20$ & 43 & $23.11 \%$ \\
\hline $21-30$ & 45 & $24.19 \%$ \\
\hline $31-40$ & 24 & $12.9 \%$ \\
\hline $41-50$ & 26 & $13.9 \%$ \\
\hline $51-60$ & 19 & $10.21 \%$ \\
\hline $61-70$ & 16 & $8.60 \%$ \\
\hline $71-80$ & 05 & $2.68 \%$ \\
\hline $81-90$ & 02 & $1.07 \%$ \\
\hline
\end{tabular}

Table 2:-Distribution of lesions according to topography:-

\begin{tabular}{|l|l|l|}
\hline Site of Involvement & No. of cases & \% of cases \\
\hline Skin \& Soft tissue & 81 & $43.50 \%$ \\
\hline Oral cavity & 36 & $19.60 \%$ \\
\hline Lymph node & 06 & $3.20 \%$ \\
\hline Thyroid & 12 & $6.40 \%$ \\
\hline Salivary gland & 17 & $9.13 \%$ \\
\hline Orbit & 13 & $6.90 \%$ \\
\hline Nasal cavity & 16 & $8.60 \%$ \\
\hline Otologic & 03 & $1.60 \%$ \\
\hline Oesophagus & 02 & $1.07 \%$ \\
\hline
\end{tabular}

Table 3:-Distribution of lesions according to histological types:-

\begin{tabular}{|r|r|r|}
\hline Type of Lesion & No. of cases & \% of cases \\
\hline Benign & 102 & $54.9 \%$ \\
\hline Inflammatory & 63 & $33.8 \%$ \\
\hline Malignant & 13 & $6.9 \%$ \\
\hline Pre malignant(dysplasia) & 08 & $4.4 \%$ \\
\hline Total & $\mathbf{1 8 6}$ & $\mathbf{1 0 0 \%}$ \\
\hline
\end{tabular}

Of all Benign lesion epidermoid cyst (50.9\%) was common followed by lipoma(11.7\%). Other benign lesion were nodular goiter(8.82\%) Epidermoid cyst(50.9\%) Mucocele(6.8\%),Hemangioma(6.8\%)Pleomorphicadenoma(3.9\%) squmouspapilloma(2.9\%) Follicular adenoma(1.96\%) Invertrdpapilloma( $0.9 \%)$,fibroma $(0.9 \%)$,chondroidsyringoma $(0.9 \%)$ hurthlecell adenoma( $0.9 \%)$,Nasopharyngeal angiofibroma $(0.9 \%)$.

In inflammatory lesion Nasal polyp(22.2\%) was predominant followed by Non specific inflammatory lesion(19.04\%). Other inflammatory lesion were Chronic tonsillitis(14.2\%) Pterygium(9.5\%) Chronic sialadenitis(6.3\%) Granulomatous lymphadenitis(6.3\%) Chronic dacryocystitis(4.7\%) Infected conjuctival $\operatorname{cyst}(4.7 \%), \operatorname{CSOM}(4.7 \%)$ Acute suppurative lymphadenits(3.17\%).

Most common malignant lesion was squamous cell carcinoma(69.2\%) involving oral cavity in all cases. Other malignant lesion were Adenoid cystic carcinoma( $7.6 \%)$, Basal cell carcinoma $(7.6 \%)$, Salivary duct carcinoma $(7.6 \%$ and Malignant melanoma(7.6\%). 


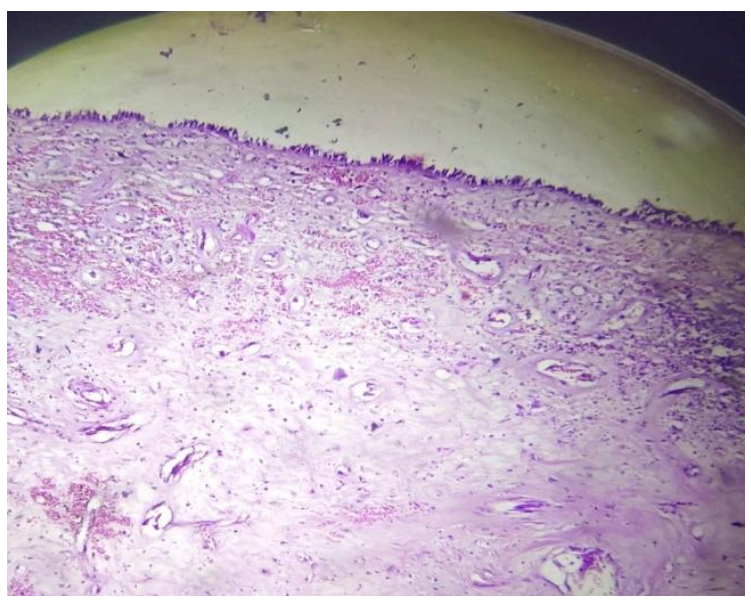

Fig 1:-Nasal Polyp, showing Psudostatified ciliated columnar epithelial lining and inflammatory infiltrate \& oedematous stroma (H\& E stain)

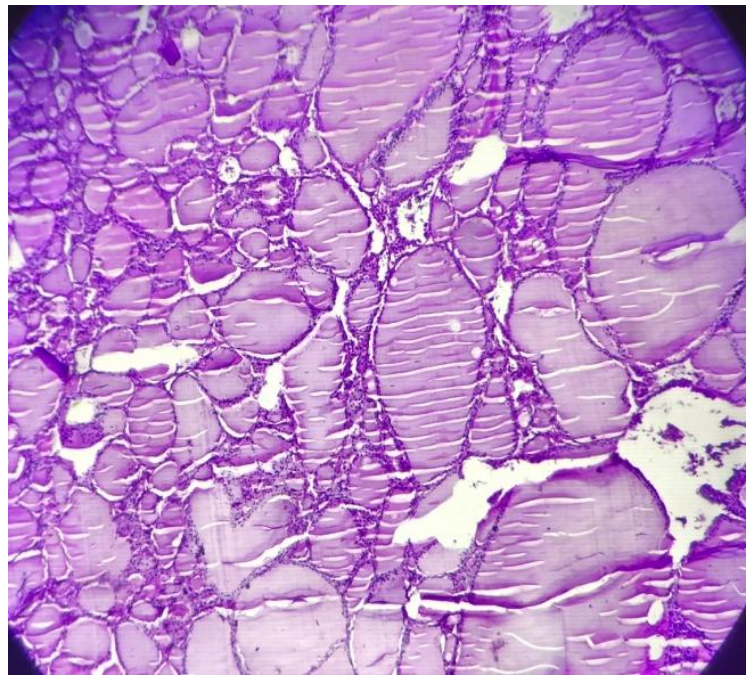

Fig 2:-Colloid goiter, Shoeing variable sized follicle lined by flattened epithelium and filled with colloid.( H\& E)

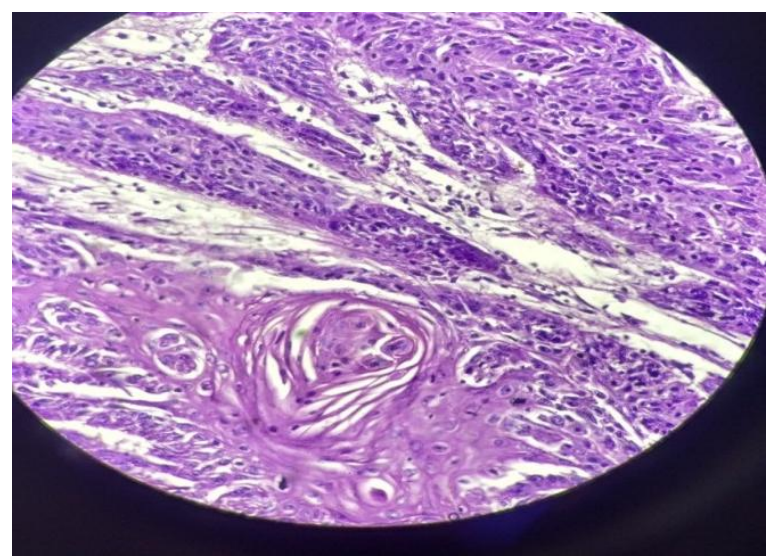

Fig. 3:-Squamous cell carcinoma, Showing sheets of dysplastic squamous epithelial cells with keratin pearls.(H\&E)

\section{Discussion:-}

In the present study, There was male preponderance with $\mathrm{M}: \mathrm{F}$ ratio was 1.16:1.Similar Observation was noted in the Sharma M et al(6) study showing M:F ratio was $1.37: 1$ and Singhal U et al(7) study with M:F ratio 2.5:1. Lesions arising from the skin and soft tissues were found to be maximum(43.50\%), compatible with Sharma M et al 
study(29.65\%). In a study by Kanu OO et al(3) and Popat $\mathrm{V}$ et al(8) more number of benign cases were reported which was compatible with our study.The most common benign lesion was epidermoid cyst(50.9\%), similar with the Singhal U et al study(7). In the present study, the general topography indicated that oral cavity was most commonly affected by squamous cell carcinoma.Squamous cell carcinoma was the most frequently encountered malignancy in Sharma M et al study(6), Compatible with our study. This could be attributed to major preventable risk factors which are tobacco use, betel quid chewing and alcohol consumption.

Out of the total cases, $6.40 \%$ of the cases of thyroid gland found in our study, Among these, most frequent entity was colloid goiter, similar findings were reported by Popat V et al(8), Urooj et al(9) and Rahman MA et al(10) in their respective studies.

\section{Conclusion:-}

Through our study we conclude that biopsy remains the gold standard for the diagnosis of head \& neck lesion. The present study highlighted the whole spectrum of lesions from head \& neck regions. Though head \& neck malignancies are a serious issue, good awareness, education and early diagnosis can reduce their incidence

\section{References:-}

1. Khetrapal S,Jetley S, Jairajapuri Z, Ratna S, Kohli S.Fnac of head \& neck lesions and its utility in clinical diagnosis: A study of 290 cases.NJMR.2015;5:33-8.

2. 2.Suryawanshi KH, Damle RP, Dravid NV, Tayde Y. Spectrum of FNAC in palpable head and neck lesions in tertiary care hospital in India- A 3 years study.IJPO.2015;2:7-13.

3. Kanu OO, Nnnoli MA, Asoegwu CA. Prevalence of head and neck tumors in calabar, South Eastern Nigeria.Asian J Med Sciences.2016;7:123-6.

4. 4.Ahluwalia H, Gupta SC, Singh M, Gupta SC, Mishra V, Singh PA. Spectrum of head and neck cancersat Allahabad.J Otolaryngeal Head Neck Surg.2001;53:16-20.

5. National Cancer Registry Programme- Biennial Report(1988-89) of the National Cancer Registry Programme. New Delhi: Indian Council of Medical Research,1992;3-42.

6. Sharma M, Sharma A, Gandhi S, Khajuria A, Goswami K.C. Histopathological pattern of head and neck lesions- a two year retrospective hopital based study.IJRMS 2017;5(4):1282-1287.

7. Singhal U, Nanda A, Lamba S, Sethi D, Jain S. Histomorphological Spectru, of Head and Neck Lesions: A Three Year Retrospective Analysis.Recent Advances in Pathology \& Laboratory Medicine 2018;4(2):1-5.

8. Popat V, Vora D, Shah H. Clinicopathological correlation of neck lesions- Astudy of 103 cases. Int J Head Neck Surg. 2013;4:119-22.

9. Urooj A, Mirza T, Ali A, Agha MA, Rasool S. Frequency of head and neck lesions according to histopathologic diagnosis. J Dow Univ Health Sciences Krachi.2011;5:70-3.

10. Rahman MA, Biswas MA, Siddika ST, Sikder AM, Talukder SI, Alamgir MH. Histomorphological pattern of thyroid lesions. Dinajpur Med Col J.2013;6:134-40. 